\title{
Legal regulation of aircraft leasing
}

\author{
Elvir Akhmetshin ${ }^{1}$, and Kseniya Kovalenko ${ }^{2 *}$ \\ ${ }^{1}$ Kazan Federal University, Elabuga Institute of KFU, Elabuga, Russia \\ ${ }^{2}$ Altai State University, Barnaul, Russia
}

\begin{abstract}
Currently, flights are an integral part of our lives. Sitting in the plane, we trust our lives not only to the crew but also to the aircraft. Today, the requirements for aviation are extremely high. But do not forget that the aircraft on which we fly are often the subject of a lease agreement. And we would like to consider the issues of aviation leasing in this article. In the legislation and the theory of civil law, there are no concepts of the contract of aviation leasing and the contract of leasing of aircraft. The leasing contract for aircraft is a contract in accordance with which the lessor undertakes to acquire into the ownership of the aircraft (plane) specified by the lessee for business or other professional purposes from the seller specified by him and provides the lessee with this property for a fee in a temporary possession and use. The contract may provide that the choice of the seller and the acquired property is determined by the lessor. In doctrine and practice, there is no consensus on the nature of the leasing agreement, nor can scientists agree on the nature of such a treaty: whether it is trilateral or bilateral, or represents two contracts (leasing and delivery). In civil law, one of the most controversial issues is whether the leasing agreement should be considered as an independent type of a civil law contract or a type of lease.
\end{abstract}

\section{Introduction}

There are no concepts of the contract of aviation leasing and the contract of leasing of aircraft in the legislation and the theory of civil law. Studies showed that the leasing contract for aircraft is a contract in accordance with which the lessor undertakes to acquire into the ownership of the aircraft (plane) specified by the lessee for business or other professional purposes from the seller specified by him and provides the lessee with this property for a fee in a temporary possession and use. The contract may provide that the choice of the seller and the acquired property is determined by the lessor.

China's rise to the world's leading trading nation in just a couple of decades has arguably been the single most important story in recent global economic history.

These five charts from the report show how remarkably China's trade has changed and is continuing to change.

\footnotetext{
*Corresponding author: kovalenko1288@mail.ru
} 
With nominal exports growing by 17 percent annually between 1990 and 2012, China now accounts for more than 12 percent of world exports and 10 percent of imports, the IMF report says.

This is more than any other country in the world. In fact, all the other major trading nations - US, Germany, Japan, France - have seen their share in global exports decrease while China's share has shot up.

As China's success has largely been based on cheap labour, its rise in labour-intensive exports is even more dramatic (Figure 1).

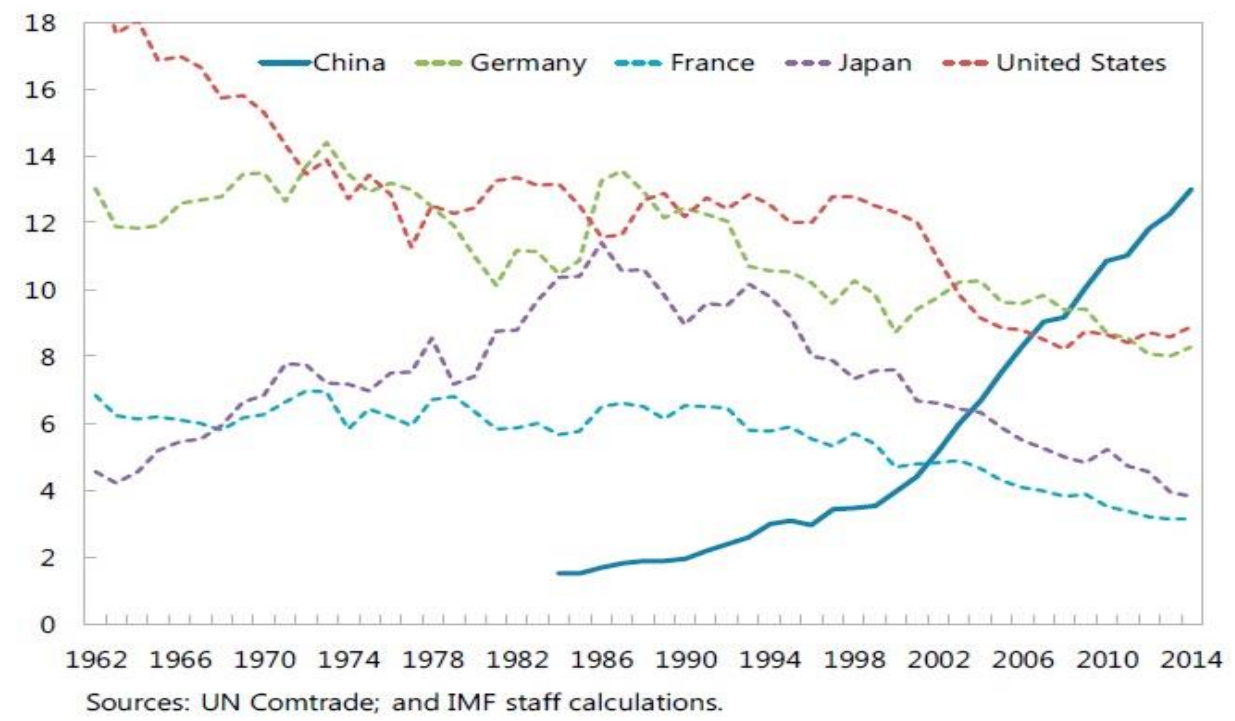

Fig. 1. Global export market share (percent, top five exporters)

How to achieve this result? We see the solution in the proper preparation of the leasing agreement and the study of the legal framework of the leasing contract.

\section{Methods}

The current research uses the methods of observation, comparative legal studies, formal logic, description, and interpretation.

Leasing applies to various types of activities in a market economy. The specificity of a financial instrument is based on the acquisition of a specific type of property for rent. The key part of the arrangements is the acquisition by the lessee of the right to full ownership of the property after the contract expires. The concept of wet leasing provides for the delivery of an aircraft with the crew for temporary use. Basic moments:

- Leasing an airplane or other air transport by the airline.

- Payment of obligations for insurance, maintenance of crew, repair and maintenance.

-The lessee of air transport takes on secondary costs (fuel supply, airport charges or taxes) (Figure 2). 


\section{The Growth of Aircraft Leasing}

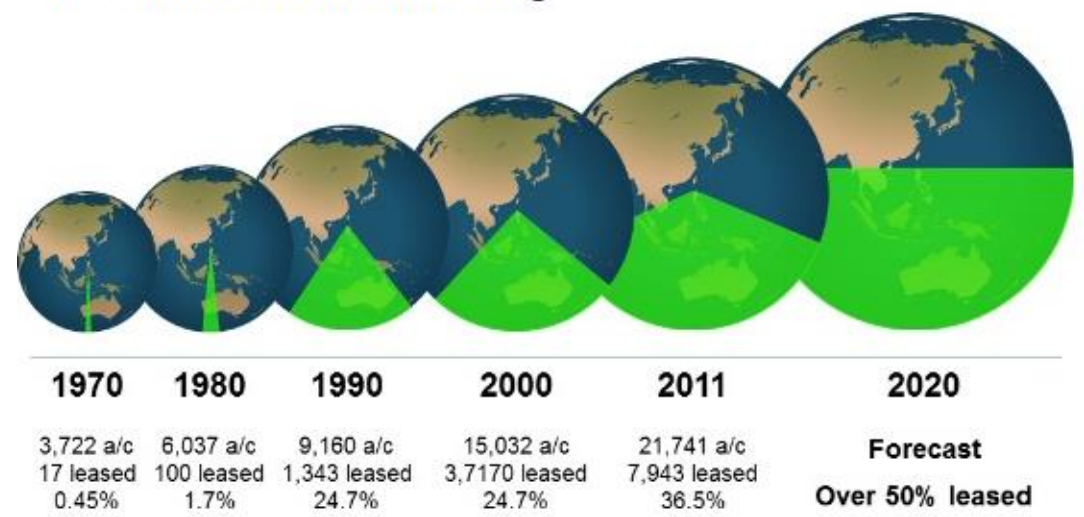

Fig. 2. Number of leasing contracts (percent) Source: Boeing

According to Art. 33 of the Air Code of the Russian Federation [1], aircraft intended for flight operations are subject to state registration in the following order:

- civil aircraft, except of ultralight civil aircraft of general aviation, in the State Register of Civil Aircraft of the Russian Federation with the issuance of certificates of state registration or in the state register of civil aircraft of a foreign state is a subject to the conclusion of an agreement on maintaining airworthiness between the Russian Federation and the state of registration;

- ultralight civil aircraft of general aviation - in the manner established by the authorized body in the field of civil aviation;

- state aircraft - in accordance with the procedure established by the authorized body in the field of defence and in consultation with authorized bodies having units of state aviation.

At the same time, the state registration of civil aircraft of the Russian Federation is a documentary confirmation by the state authority of the Russian Federation of the extension of the jurisdiction of the state [8] to this aircraft with the resulting obligations of the owner, operator and state in accordance with the requirements of the RF Air Code and international agreements [9]. Due to such registration, the aircraft registered in the Russian Federation acquires the nationality of the Russian Federation, as well as the acquisition of nationality by aircraft in foreign countries.

The legal basis for this definition was the Air Code of the Russian Federation [1], which defines the term "aircraft"; Federal Law (FL) "On State Regulation of Civil Aviation Development"[2], which defines the concepts "aviation technology", "aircraft"; FL "On financial leasing (leasing)" [3], which contains the definition of the contract of financial leasing; The UNIDROIT Convention [4], which establishes the concept and purpose of concluding a leasing agreement.

The wording of the leasing agreement will differ from the leasing contract for aircraft only, i.e. a lessor can acquire not only an aircraft for a lessee but also other aviation equipment intended for business purposes.

In civil law, one of the most controversial issues is whether the leasing agreement should be considered an independent type of a civil law contract or a type of lease.

In the legal literature, the view that the leasing agreement is an independent type of civil law contracts is actively advocated by I.A. Reshetnik. In her opinion, the leasing agreement "integrates various elements inherent in nature, among which we can distinguish features of rental type, purchase and sale, agreements on rendering legal and actual services. At the 
same time, the combination in the leasing agreement of the elements of the contractual constructions known to the legislation has generated special qualities and attributes that characterize the specific legal essence of this treaty "[5].

As a result, the author comes to the conclusion that the norms on the leasing agreement that characterize it as a separate type of the contract are combined into an independent regulatory legal entity - a legal institution that, being a relatively separate "block" of civil law as an industry, fully corresponds to the basic criteria of the concept of "the institution of law" formulated by the theory of law.

Supporters of another position are M.I. Braginsky and V.V. Vitriansky [6], who, like most scientists, believe that the lease agreement is a separate type of lease. They give the following arguments:

- the recognition of the leasing agreement as an independent contract will require the isolation of its regulatory standards into a separate chapter and the inclusion of general provisions on leasing, which will lead to a duplication of norms;

- the attitude to the leasing agreement as an independent contract follows from the conclusion that the contract is a trilateral transaction, although the leasing relationship is mediated by two contracts: leasing and sale (contract in favor of a third party);

- contracts recognized by the Civil Code of the Russian Federation as independent contractual types usually have significant differences in almost all their elements: subject, subject composition, content. Comparing the leasing contract and the lease agreement as a whole with the traditional elements for any civil-law contract, we find serious differences only in the subject matter.

Considering the leasing contract as a type of lease, some authors distinguish its characteristic features. Such signs consist in a longer term of equipment rent and in the peculiarities of payment conditions. As a rule, the lease term of the equipment is approaching the term of its effective operation, i.e. full depreciation, and the total amount of payments exceeds the value of the property, its purchase price. This agreement is also characterized by a different distribution of rights and obligations between the parties than in the lease agreement.

So, according to the general rule, the risk of accidental death, accidental damage to property is borne by its owner (Article 211 of the Civil Code of the Russian Federation) [7], since otherwise is not provided for by law or contract. Under the leasing agreement, the lessor remains the owner of the leased property, but the risk of accidental loss or accidental damage to the leased property is borne by the lessee from the moment of transfer of the leased property to him, unless otherwise provided by the leasing agreement (Article 669 of the Civil Code of the Russian Federation) [7]. The parties involved in the leasing contract for aircraft are the lessor and the lessee.

\section{Results}

At present, the state registration of civil aircraft of the Russian Federation is carried out in accordance with the Rules of State Registration of Civil Aircraft of the Russian Federation [10] and has the following task [11]:

Accounting for all civil aircraft of the Russian Federation flying in the airspace of the Russian Federation and beyond. Determination of the nationality of the aircraft, the vessel's belonging to a particular state. Legal registration of the ownership and operation of this aircraft. Concentration in the state body of information on civil aircraft.

In civil aviation under the Chicago Convention of 1944, proper aircraft registration serves as the fundamental basis for international air transport. Further details on the registration and identification of civil aircraft are contained in Annex 7 to the 1944 Chicago Convention: each aircraft must be registered in one of the States, and each State should 
maintain a register of civil aircraft. No aircraft can have a valid registration in more than one state, but a change of registration from one state to another is possible. The state of registration of each aircraft entered in the state register assumes the obligation to ensure the safe operation of this aircraft. Flights of unreported (unaccounted) aircraft are not allowed. Aircraft not intended for flights (used, for example, as monuments, training aids). A special accounting procedure is adopted for ultralight aircraft of general aviation, meteorological balloons and unmanned uncontrolled balloons.

It should be noted that additional rules for the registration of aircraft are established with respect to state aircraft, which are subject to state registration in accordance with the Federal Aviation Rules for the State Registration of State Aircraft [12]. These rules establish the general procedure for the state registration of state aircraft, their registration in the State Register of State Aircraft of the Russian Federation in an approved form. The rules are mandatory for all federal executive bodies and organizations that have state aviation units. Civil aircraft are registered in the appropriate registry maintained by the Federal Air Transport Agency in accordance with the Rules of State Registration of Civil Aircraft of the Russian Federation.

It should be noted that when data on a civil aircraft are included in the State Register, the registration authority assigns to it the state and registration identification marks that are affixed to a civil aircraft (paragraph 30 of the Rules of State Registration of Civil Aircraft of the Russian Federation). Without the identification signs inflicted in accordance with the requirements of the Rules on the elements of the civil aircraft design, flights are not made. Simultaneous drawing on a civil aircraft of identification marks of the different states is not supposed. In this case, the procedure for issuing a certificate of airworthiness (certificate of airworthiness) is approved in the relevant Federal Aviation Regulations "Aircraft specimen. Requirements and certification procedures" [13].

However, in general, the admission to operation of state aircraft is carried out in accordance with the procedure established by the Government of the Russian Federation in the Rules for the admission to operation of state aircraft [14], according to which the state aircraft is allowed to operate after its manufacture in accordance with the regulatory and technical documentation before its commissioning in accordance with the established procedure, as well as after its repair connected with decommissioning of the state airspace.

At the same time, on the basis of the positive results of the verification activities in the form of the state aircraft, a record is made of the state aircraft's operational capability, which is the basis for allowing the state aircraft to operate.

It should be noted that when leasing aircraft, there is a problem of segregation of property (equipment) leased. In this case, we mean the isolation of the most expensive parts, not aircraft and not the vessel itself, for example, aircraft engines.

According to the provisions of the Convention on International Financial Leasing [4], the law applicable to equipment that normally moves from one country to another, including aircraft engines, is the law of the State in which the principal place of business of the lessee is located (Article 7). Thus, the rule relating to aircraft engines contains a different collision relation than the general rule on aircraft. The law applicable to the relations of international financial leasing (for an aircraft registered under the Convention on International Civil Aviation) signed in Chicago on December 7, 1944, is the law of the state in which this aircraft was registered. [15]

The Convention on International Interests in Mobile Equipment signed in Cape Town on November 16, 2001 provides for provisions to protect property rights and other proprietary rights to mobile equipment. As a conclusion, we would like to note that despite the fact that in the coming years the Ministry of Finance of Russia intends to increase budget expenditures to support aircraft construction, most of these funds will be used to 
subsidize interest rates and support leasing for the purchase of aircraft by Russian airlines, the aircraft leasing market remains quite undeveloped and not entirely effective.

We believe that successful development of this sector requires state support, which can be expressed both through direct financial assistance and the creation of a leasing company with state participation on the basis of the United Aircraft Corporation to encourage the leasing of domestic aircraft.

\section{Conclusions}

In doctrine and practice, there is no consensus on the nature of the leasing agreement, nor can scientists agree on the nature of such a treaty: whether it is trilateral or bilateral, or represents two contracts (leasing and delivery). In the Russian legal system, the leasing contract is regarded as a type of lease.

The leasing agreement is the most common reason for registering the right to an aircraft. This is due to the fact that today not every airline can afford to own such a mode of transport. Indeed, leasing is much more economical than buying. But is it safer? After all, air carriers often leased previously used vessels.

V.D. Bordunov faithfully notes that for the airline-lessee, the benefit of leasing is that it is possible to operate the aircraft of the required type and capacity without paying its full value immediately, which allows expanding and renewing its fleet without drastic financial costs [16]. For a lessor, leasing an aircraft is an advantageous way of investing capital and a means of effectively placing free monetary assets. Since they are invested in property, unlike money loans, the risk of non-return of funds is reduced. The undoubted advantage of leasing for the aircraft manufacturer, their seller, is the ability to obtain the full cost of the aircraft at the expense of the intermediary - the leasing company. The manufacturer undertakes to perform maintenance of the aircraft, which is very beneficial for the leasing user. For him, there is no need to hire special workers for his current and preventive maintenance, and the manufacturer himself is able to quickly identify the operational and constructive shortcomings of the aircraft during its operation by the lessee. Another positive aspect of leasing is the active and dynamic influence on the development of the aircraft rental market, which allows expanding the sales of new aircraft for their manufacturers.

But let's see, what is an aircraft? According to Article 32 of the Air Code of the Russian Federation of March 19, 1997, No. 60-FZ, it means an aircraft maintained in the atmosphere by interaction with air other than interaction with air reflected from the surface of the earth or water. And by virtue of Art. 33 of this Code, civil aircraft are subject to state registration. At the same time, the state registration of civil aircraft of the Russian Federation is a documentary confirmation by the state authority of the Russian Federation of the extension of the jurisdiction of the state to this aircraft with the ensuing obligations of the owner, operator and state in accordance with the requirements of the RF Air Code and international agreements. In the legislation, as well as in the scientific literature, there is no definition of an aircraft leasing contract, but based on the analysis of norms, it is possible to propose a variant of the definition: "The leasing agreement of aircraft is a contract whereby the lessor undertakes to acquire the aircraft (aircraft) intended by the lessee for business or other professional purposes into the possession of the seller specified by him and provide the lessee with this property for a fee of temporary possession and use. The contract may provide that the choice of the seller and the acquired property is determined by the lessor". Characterization of the parties to the aircraft leasing contract must begin with one of the most controversial issues in legal literature directly related to the parties to the transaction.

According to some scientists, the leasing agreement is a trilateral deal. Thus, I.A. Reshetnik [5] believes that the trilateral nature of the leasing agreement has a "deeply 
objective basis," since "property relations are formed as follows: one party (potential lessee), due to the lack of financial means to acquire property in ownership or as a result of the need only temporary possession or use, appeals to the other party (the potential lessor) to purchase the necessary equipment from a third party (seller) and put this equipment in temporary possession or use".

It motivates it by the fact that the leasing deal includes 2 contracts: the purchase and sale contract (the leasing company buys certain property from the company at the request of the user) and the transfer of equipment for temporary use (the leasing company becomes the owner of the equipment and transfers it for temporary use on the basis of an independent contract). It should be noted that the UNIDROIT Convention "On International Financial Leasing" is based on consideration of leasing as a trilateral transaction. In paragraph 1 of Art. 1 of the Convention states that for this transaction, "one party (the lessor):"

(a) concludes a contract (contract of supply) with the third party (supplier) under the specification of the other party (lessee), according to which the lessor acquires the complete equipment, means of production or other equipment on terms approved by the lessee insofar as they affect its interests, and

b) concludes a contract (lease agreement) with the lessee, granting him the right to use the equipment instead of paying periodic payments ".

As a conclusion, we would like to note that, despite the fact that in the coming years the Russian Finance Ministry intends to increase budget expenditures to support aircraft construction, most of these funds will be used to subsidize interest rates and support leasing for the purchase of aircraft by Russian airlines, the air leasing market ships remains quite undeveloped and not entirely effective.

We believe that for the successful development of this sector, government support is needed. It can be expressed both through direct financial assistance and the creation of a leasing company with state participation on the basis of the United Aircraft Corporation to encourage the leasing of domestic aircraft.

\section{References}

1. URL:

http://www.consultant.ru/cons/cgi/online.cgi?base $=$ LAW\&n=304188\&dst=42949672 95\&cacheid=89B1DFF9DFB1315B178BBAF87058A0D9\&mode=rubr\&req=doc\&rn $\mathrm{d}=$ DA3F551662AB8B78C228FDF1333E99EF\#0014349369767399978.

2. URL: http://www.consultant.ru/document/cons_doc_LAW_17410/

3. URL: http://www.consultant.ru/cons/cgi/online.cgi?req=doc\&ts $=1605483$ $885048698168553918353 \&$ cacheid $=10 D 9778 B D C 07 F 4 F F 733 C A 8 C B E 97 D F 747 \& \mathrm{~m}$ ode $=$ splus \&base $=$ LAW \&n=280491\&rnd=47F6DBB672FDF74D37F42EB237627B4.

4. URL: http://www.consultant.ru/document/cons_doc_LAW_14121.

5. I.A. Reshetnik. Civil-law regulation of leasing in the Russian Federation. (Perm, 1998)

6. M.I. Braginsky, V.V. Vitriansky. Contract law. Book One: General Provisions. (Moscow, 2000)

7. URL: http://www.consultant.ru/cons/cgi/online.cgi?base $=L A W \& n=294690 \& d s t=$ 429496

7295\& cacheid $=6$ EAAB88D342A76CCFB97B0D5658E0426\&mode $=$ rubr\&req $=$ doc $\&$ rnd=DA3F551662AB8B78C228FDF1333E99EF\#07428796849859929.

8. K.E. Kovalenko. World Applied Sciences Journal, 7 (2014) 
9. A.M. Simonenko, O.N. Troitskaya. Commentary to the Air Code of the Russian Federation (article-by-article). (Moscow, 2007)

10. Order of the Ministry of Transport of the Russian Federation of 02.07.2007 No 85 "On Approval of the Rules for the State Registration of Civil Aircraft of the Russian Federation". Bulletin of Normative Acts of Federal Executive Bodies, 41 (2007)

11. N.V. Vartanyan. On the procedure for state registration of civil aircraft. Transport Law, 3 (2009)

12. Order of the Minister of Defense of the Russian Federation of 28.11.2002 No. 460 "On Approval of Federal Aviation Rules for State Registration of State Aircraft". Bulletin of Normative Acts of Federal Executive Bodies, 20 (2003).

13. Order of the Ministry of Transport of the Russian Federation No. 132 of May 16, 2003 "On Approval of Federal Aviation Regulations" A copy of an aircraft. Requirements and certification procedures ". Rossiyskaya Gazeta, 116 (2003)

14. Decree of the Government of the Russian Federation No. 766 of September 12, 2011 "On admission to operation of state aircraft". SZ RF, 38 (2011)

15. M.P. Bardina, B.A. Bulaevsky, N.G. Vilkova. Commentary on the Civil Code of the Russian Federation. (Moscow, 2010).

16. V.D. Bordunov. International Air Law (Moscow, 2007). 